\title{
Pelatihan Pemanfatan Quick Responde Code Technology dalam Pengembangan Media Pembelajaran
}

\author{
Dewi Anjani', Desi Novianti*2, Ali Sadikin Wear ${ }^{3}$ \\ 1,2 Teknik Informatika/Universitas Indraprasta PGRI \\ ${ }^{3}$ Teknologi Pengangkapan Ikan/ Politeknik Perikanan Negeri Tual \\ *e-mail: dewiunindra@gmail.com¹, desi.novi4nti@gmail.com² ${ }^{2}$ alisadikin.wear@polikant.ac.id ${ }^{3}$
}

\begin{abstract}
Revolution 4.0 resulted in teachers having to continue to improve their abilities, especially in making learning media. Learning media is one of the teacher's tools to transfer knowledge to students. With the suitable media, the level of student understanding of the lesson will increase. During this pandemic, the learning method used is online. Teachers only provide material in the form of files in document format. Giving such learning materials makes students less interested in learning which causes a decrease in understanding of the material. From these problems, we need a learning media that can make students understand the material, which gives students enthusiasm in learning, namely by changing the learning media used today. One of the learning media that can increase students' interest in learning is interactive media, such as $Q R$ Code technology. For this reason, teachers need knowledge and understanding of making learning media using $Q R$ Code s. To support this, the school held community service activities. The activity aims to introduce and provide training on $Q R$ Code Technology in the Development of Learning Media at SDN 15 Pal Merah, West Jakarta, so learning is more exciting and interactive.
\end{abstract}

Keywords: $Q R$ Code, learning Media, Interactive learning

\begin{abstract}
Abstrak
Revolusi 4.0 mengakibatkan guru harus terus meningkatkan kemampuannya terutama dalam pembuatan media peembelajaran. Media pembelajaran adalah salah satu alat bantu guru untuk mentransfer ilmu kepada siswa. Dengan media yang tepat maka tingkat pemahaman siswa terhadap pelajaran akan meningkat. Masa pandemi ini metode pembelajaran yang digunakan adalah daring, dimana guru hanya memberikan materi berupa file dalam format dokumen. Hal ini membuat siswa kurang berminat untuk belajar yang menyebabkan penurunan terhadap pemahaman materi. Dari permasalahan tersebut, maka dibutuhkan sebuah media pembelajaran yang bisa membuat siswa dapat memahami materi pelajaran yang memberikan antuisme dalam belajar, yaitu dengan cara mengubah media pembelajaran yang digunakan saat ini. Salah satu media pembelajaran yang dapat meningkatkan minat belajar siswa adalah media yang interaktif seperti penggunaan $Q R$ Code technology. Untuk itu guru memerlukan pengetahuan dan pemahaman tentang pembuatan media pembelajaran yang menggunakan $Q R$ Code. Untuk menunjang hal tersbut, maka diadakan sebuah kegiatan pengabdian kepada masyarakat yang memperkenalkan dan pemberian Pelatihan Pemanfatan QR Code Technology dalam Pengembanngan Media Pembelajaran pada sekolah dasar 15 pal merah, Jakarta barat, sehingga pembelajaran lebih menarik dan interaktif.
\end{abstract}

Kata kunci: QR Code , Media Pembelajaran, Pembelajaran Interaktif

\section{PENDAHULUAN}

Revolusi industry 4.0 berarti dunia telah mengalami empat tahapan revolusi, yaitu: 1) Revolusi Industri 1.0 terjadi pada abad ke 18 melalui penemuan mesin uap, sehingga memungkinkan barang dapat diproduksi secara masal, 2) Revolusi Industri 2.0 terjadi pada abad ke 19-20 melalui penggunaan listrik yang membuat biaya produksi menjadi murah, 3) Revolusi Industri 3.0 terjadi pada sekitar tahun 1970an melalui penggunaan komputerisasi, dan 4) Revolusi Industri 4.0 sendiri terjadi pada sekitar tahun 2010an melalui rekayasa intelegensia dan internet of thing sebagai tulang punggung pergerakan dan konektivitas manusia dan mesin (Prasetyo \& Trisyanti 2018). Kamajuan teknologi informasi tersebut mempermudah terhubungnya manusia satu sama lainnya (Yandra:2018). 
Perkembangan industri 4.0 berdampak terhadap berbagai bidang termasuk dalam bidang pendidikan. Dimana proses dalam kegiatan belajar mengajar saat ini memanfaatkan teknologi digital (Davis 2015). Hal ini menyebabkan seluruh komponen Pendidikan harus berevolusi terutama guru dan siswa.

Guru sebagai pemimpin dalam pembelajaran dituntut untuk mampu beradaptasi dan siap berubah, agar dapat menghadapi tantangan di era industri 4.0 (Burritt \& Christ 2016). Guru diperlukan untuk membentuk karakter siswa, teladan yang menumbuhkan semangat, kreativitas dan empati sosial. Salah satu tuntutan tersebut adalah memberikan Pembelajaran kepada siswa berdasarkan tantangan di era industri 4.0, yaitu menyesuaikan media pengajaran yang awalnya konvensional, dapat diubah menjadi media pembelajaran yang berbasis teknologi. Dengan menggunakan teknologi media pembelajaran dapat dibuat menarik dalam penyampaian materi dan mengkombinasikan beberapa metode pembelajaran tidak hanya meggunakan metode ceramah saja (Sari et al. 2021). Salah satu teknologi yang dapat dimanfaatkan adalah teknoogi yang dapat dimanfaatkan adalah $Q R$ Code.

$Q R$ Code merupakan sebuah gambar dua dimensi yang menyajikan sebuah data, terutama data berbentuk teks. $Q R$ Code merupakan perkembangan dari sebuah barcode yang awalnya satu dimensi menjadi dua dimensi. $Q R$ Code berisi informasi baik diarah vertikal dan horizontal, sedangkan bar code berisi data dalam satu arah saja (gambar 1). $Q R$ Code memiliki ukuran yang lebih besar informasi dari bar code (Saenab et al. 2017; A. S. Narayanan 2012).

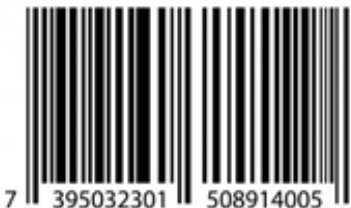

(a)

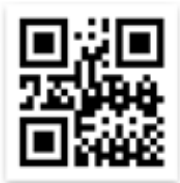

(b)

\section{Gambar 1. (a) Gambar Barcode (b) Gambar QR Code}

Sekolah Dasar 15 Palmerah, Jakarta Barat merupakan tempat pendidikan anak yang berusia antara 7 sampai dengan 13 tahun, sebagai pendidikan di tingkat dasar yang dikembangkan sesuai dengan satuan pendidikan, potensi daerah/karakteristik daerah, sosial budaya masyarakat setempat bagi siswa. Berdasarkan observasi lapangan dan wawancara pada tanggal 10 april 2021 pembelajaran yang dilaksanakan guru pada SD 15 menggunakan metode Daring, dimana metode ini memanfaatkan jaringan online. Guru akan memberikan bahan ajar kepada orang tua melalui media online seperti aplikasi WhatsApp dan Classrom. Kemudian siswa akan belajar dirumah yang didampingi oleh orang tua, dan mengirimkan tugas sesuai yang diperintahkan melalui media yang sama. Dan berdasarkan wawancara dengan wali murid didapatkan bahwa permasalahan dalam metode daring ini adalah guru hanya memberikan materi berupa file dalam format dokumen. Hal ini membuat siswa mengurangi minat siswa untuk belajar. Sehingga menggangu proses pembelajaran. Sementara dalam pembelajaran dibutuh proses komunikasi yang baik.

Dari permasalahan diatas, maka dibutuhkan sebuah media pembelajaran yang bisa membuat siswa dapat memahami materi pelajaran yang memberikan antuisme siswa dalam belajar, yaitu dengan cara mengubah media pembelajaran yang digunakan saat ini. Salah satu media pembelajaran yang dapat meningkatkan minat belajar siswa adalah media yang interaktif seperti penggunaan $Q R$ Code technology. Untuk itu guru memerlukan pengetahuan dan pemahaman tentang pembuatan media pembelajaran yang menggunakan $Q R$ Code. Untuk memecahkan masalah tersebut, maka diadakan 
sebuah kegiatan pengabdian kepada masyarakat yang memperkenalkan dan pemberian Pelatihan Pemanfatan $Q R$ Code Technology dalam Pengembangkan Media Pembelajaran pada sekolah dasar 15 pal merah, Jakarta barat, sehingga pembelajaran lebih menarik dan interaktif. Media pembelajaran dapat menggantikan fungsi guru sebagai sumber informasi atau pengetahuan bagi siswa, pada penelitian (Desyanti, Muztazihim Suhaidi 2019) menggunakan media pembelajaran audio visual untuk meningkatkan kemampuan siswa dalam menghafal juz amma.

\section{METODE}

Model pelaksanaan program pelatihan ini dilakukan secara daring, mulai dari penyampaian materi, praktek hingga evaluasi. Dengan melibatkan 3 orang Pemateri dan 20 orang guru SDN 15 Pagi Palmerah, Jakarta Barat sebagai peserta. Pelaksanaan kegiatan pelatihan ini dilaksanakan sesuai waktu yang sudah direncanakan dan disepakati bersama instansi terkait dan peserta pelatihan. Pelaksanaan ini dilaksanakan 4 hari yaitu pada bulan Juli tahun 2021, setiap hari Jumat dimulai jam 13.00 hingga 15.30. Sementara gambaran Ipteks yang akan ditransfer kepada mitra dapat dilihat pada tabel 1.

Tabel 1. Gambaran Ipteks Yang Akan Ditransfer Kepada Mitra

\begin{tabular}{|c|c|c|}
\hline No & $\begin{array}{c}\text { Jenis IPTEK yang akan } \\
\text { ditransfer kepada } \\
\text { Mitra }\end{array}$ & Diskripsi Iptek \\
\hline 1. & $\begin{array}{l}\text { Pengenalan } Q R \quad \text { Code } \\
\text { Technology dan Bahan } \\
\text { ajar yang interaktif }\end{array}$ & $\begin{array}{l}\text { Memberikan penjelasan manfaat } Q R \text { Code } \\
\text {, implementasi bahan ajar } Q R \text { Code yang } \\
\text { interaktif, dan menjelaskan cara kerja } Q R \\
\text { Code }\end{array}$ \\
\hline 2. & $\begin{array}{l}\text { Pelatihan menyiapkan } \\
\text { aplikasi yang dibutuhkan } \\
\text { untuk membuat } Q R \text { Code } \\
\text { baik di Personal } \\
\text { Computer (PC) maupun di } \\
\text { Operating System (OS) } \\
\text { Android }\end{array}$ & $\begin{array}{l}\text { Mendemontrasikan dan langsung } \\
\text { mempraktikan cara mem-generate } Q R \\
\text { Code menggunakan PC dan OS android. }\end{array}$ \\
\hline 3. & $\begin{array}{l}\text { Pelatihan pembuatan } \\
\text { Bahan ajar dengan } \\
\text { memanfaatkan } Q R \text { Code }\end{array}$ & $\begin{array}{l}\text { Mendemontrasikan dan langsung } \\
\text { mempraktikan cara membuat bahan ajar } \\
\text { yang interkatif menggunakan } Q R \text { Code }\end{array}$ \\
\hline
\end{tabular}

\section{HASIL DAN PEMBAHASAN}

Perkembangan ilmu pengetahuan dan teknologi semakin mendorong upaya-upaya pembaharuan dalam pemanfaatan hasil-hasil teknologi dalam proses belajar mengajar. Para guru dituntut agar mampu menggunakan alat-alat yang dapat disediakan oleh sekolah, dan tidak tertutup kemungkinan bahwa alat-alat tersebut sesuai dengan perkembangan dan tuntutan zaman (Hasibuan 2019). Guru sekurang-kurangnya dapat menggunakan alat yang murah dan bersahaja tetapi merupakan keharusan dalam upaya untuk mengembangkan supaya mencapai tujuan pengajaran yang diharapkan.

Di samping mampu menggunakan alat-alat yang tersedia, guru juga dituntut untuk dapat mengembangkan alat-alat yang tersedia, guru juga dituntut untuk dapat 
mengembangkan keterampilan membuat media pengajaran yang akan digunakannya apabila media tersebut belum tersedia (Supriyanto 2018).

Pengabdian masyarakat ini dilakukan dengan tujuan untuk memberikan kontribusi dalam inovasi pembelajaran terutama dalam pembuatan bahan ajar. Dimana bahan ajar yang akan dibuat adalah bahan yang interaktif, sehingga lebih menarik terutama untuk anak-anak pada tingkat sekolah dasar.

Pada tahap pendahuluan, hasil dari survei yang diadakan awal bulan april 2021 adalah kondisi yang tidak memungkinkan untuk melaksanakan kegiatan secara tatap muka karena masih dalam kondisi pandemic covid, sehingga kegiatan akan dilaksanakan secara online dengan menggunakan media Zoom.

Tahapan persiapan, merupakan tahapan untuk menyiapkan bahan seperti slide presentasi, modul, link zoom, dan penilaian awal dan akhir. Kemudian persiapan waktu pelaksanaan yang dikoordinasi wakil tim dengan perwakilan sekolah. Dari kegiatan ini dijadwalkan kegiatan akan dilaksanakan pada tanggal 2-23 juli 2021, yang dilaksanakan setiap hari jumat jam 13.00-15.30.

Tahapan pelaksanaan yaitu melakukan pelatihan pembuatan bahan ajar yang interaktif menggunakan $Q R$ Code . Dimana peserta pelatihan adalah guru, yang semua berjumlah 20 orang. Pelaksanaan ini dilaksanakan 4 hari yaitu pada bulan Juli setiap hari Jumat.

Hari pertama pelaksanaan pada tanggal 2 juli 2021 jam 13.00, kegiatan berupa Pengenalan $Q R$ Code Technology dan bahan ajar yang interaktif. Sebelum menjelaskan lebih dalam tentang materi $Q R$ Code, maka kegiatan diawali dengan pemberian google form, tentang pengenalan dan pemahaman peserta tentang bahan ajar yang interaktif menggunakan $Q R$ Code. Hal ini dimaksudkan, untuk mengetahui tingkatan pemahaman peserta tentang bahan ajar yang interaktif terutama menggunakan $Q R$ Code.

Setelah 15 menit pengisian google form, kegiatan dilanjutkan dengan presentasi dari tim tentang penjelasan sejarah, manfaat $Q R$ Code, implementasi bahan ajar dengan $Q R$ Code yang interaktif, dan menjelaskan cara kerja $Q R$ Code .

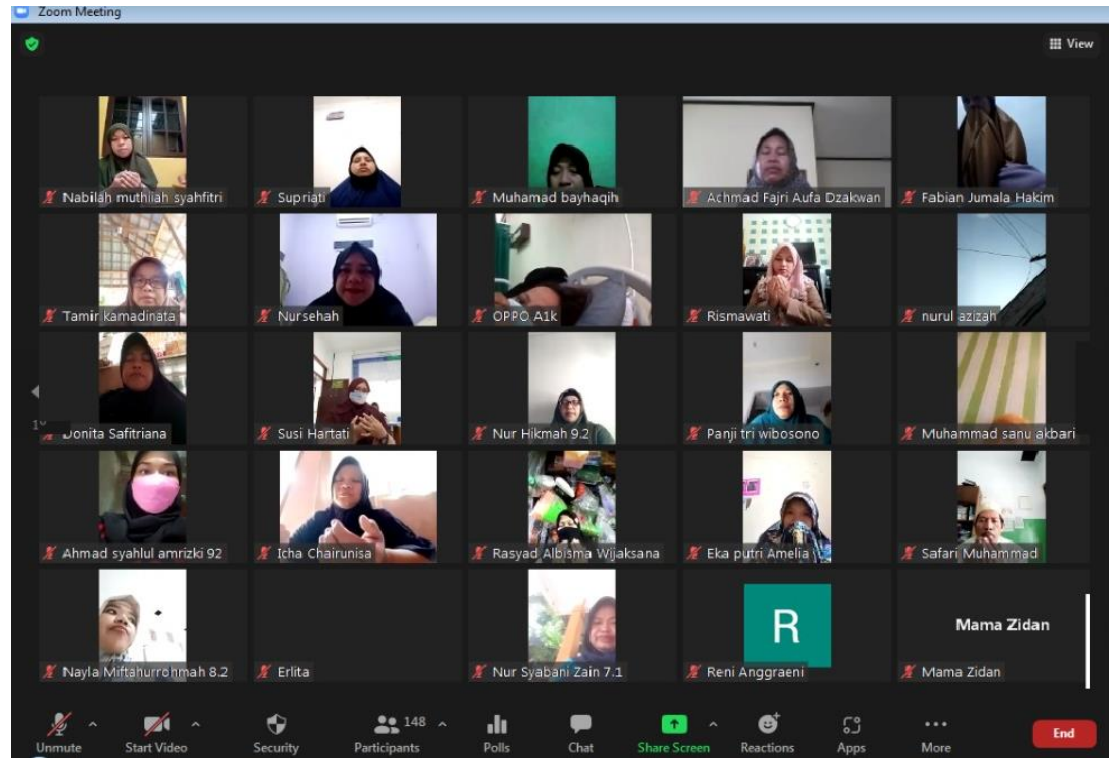

Gambar 2. Peserta PKM 
Hari kedua pelaksanaan pada tanggal 9 juli 2021 jam 13.00, kegiatan ini berupa Pelatihan mempraktikan cara mem-generate $Q R$ Code menggunakan $\mathrm{PC}$ dan OS android. Dimana materi yang dipraktikan seperti :

1. Situs generate $Q R$ Code

Tim memberikan penjelasan bagaimana membuat $Q R$ Code melalui situs yang ada sepeti flowcode, the-qrcode-generator, Kaywa, GOQR.me, Visualead, dan $Q R$ Stuff.

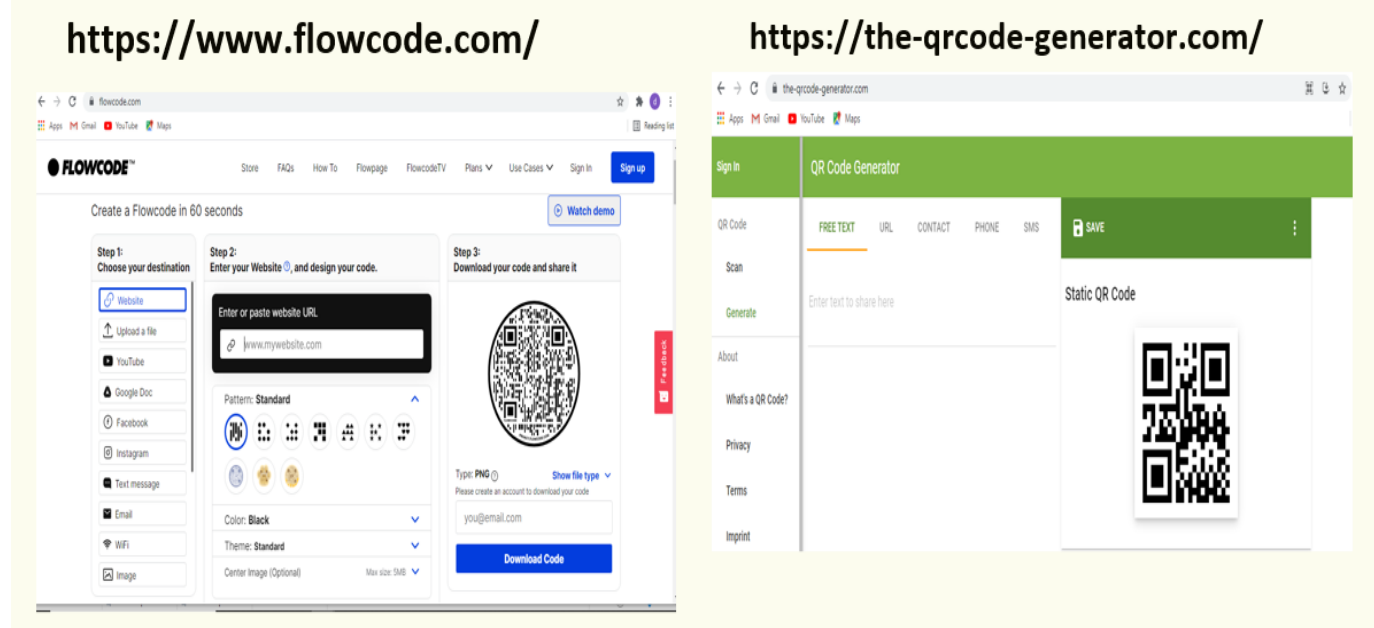

\section{Gambar 3. contoh situs Generate QR Code}

2. Tipe data

Ada beberapa tipe data yang bisa dibuat $Q R$ Code, seperti:

a. Tautan sebuha website, youtube, google doc, facebook, instagram, dan email

b. File dokumen

c. Vcard

d. Teks

e. Kegiatan / event

f. Lokasi

g. No telp

3. Cara Generate $Q R$ Code

Tim menjelaskan membuat $Q R$ Code, dimana situs yang digunakan untuk praktik adalah https://www.flowcode.com/ dan https://the-qrcode-generator.com/. Theqrcodegenerator. Com digunakan karena sederhana dalam membuat $Q R$ Code sehingga memudahkan peserta untuk memahami. Sementara flowcode.com, dapat memberikan $Q R$ Code yang unik bukan hanya dalam bentuk segi empat yang biasa dilihat namun bisa membuat pola sendiri.

Dimana setelah masuk situs nya, maka pilh tipe data, masukkan data yang akan dibuat kemudian data tersebut langsung tergenerate menjadi $Q R$ Code, dan kode tersebut bisa lngsung disimpan seperti gambar 2 . 


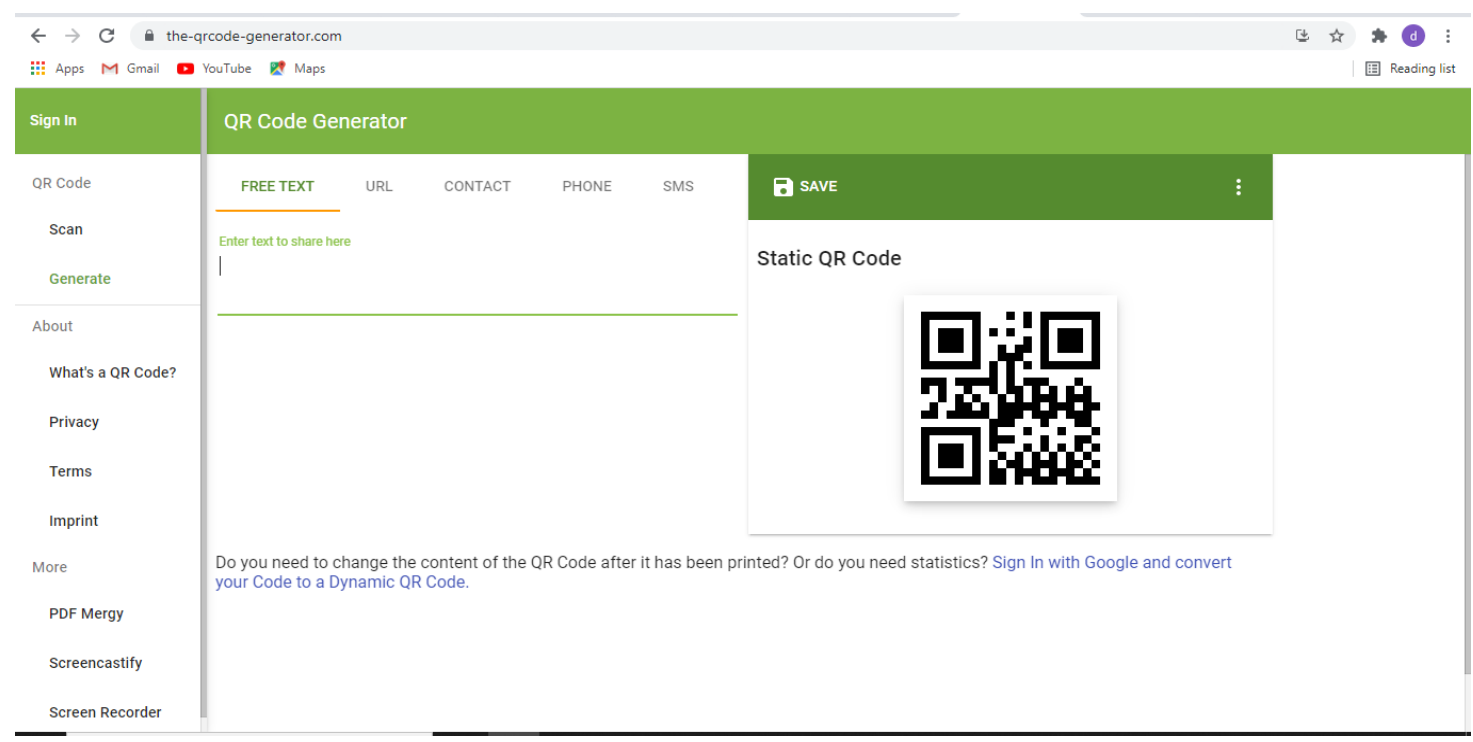

\section{Gambar 4. halaman untuk generate $Q R$ Code} pada https://the-qrcode-generator.com/

4. Uji QR yang dibuat

$Q R$ Code yang telah dibuat dapat dilihat menggunakan aplikasi pada smartphone seperti aplikasi google Search by Image, atau menggunakan aplikasi $Q R$ Code Reader yang lain yang dapat di download pada google playstore secara gratis.

5. Implementasi bahan ajar dengan $Q R$ Code

Tim juga telah mempraktikan pembuatan bahan ajar dengan $Q R$ Code seperti telihat pada gambar 4 .

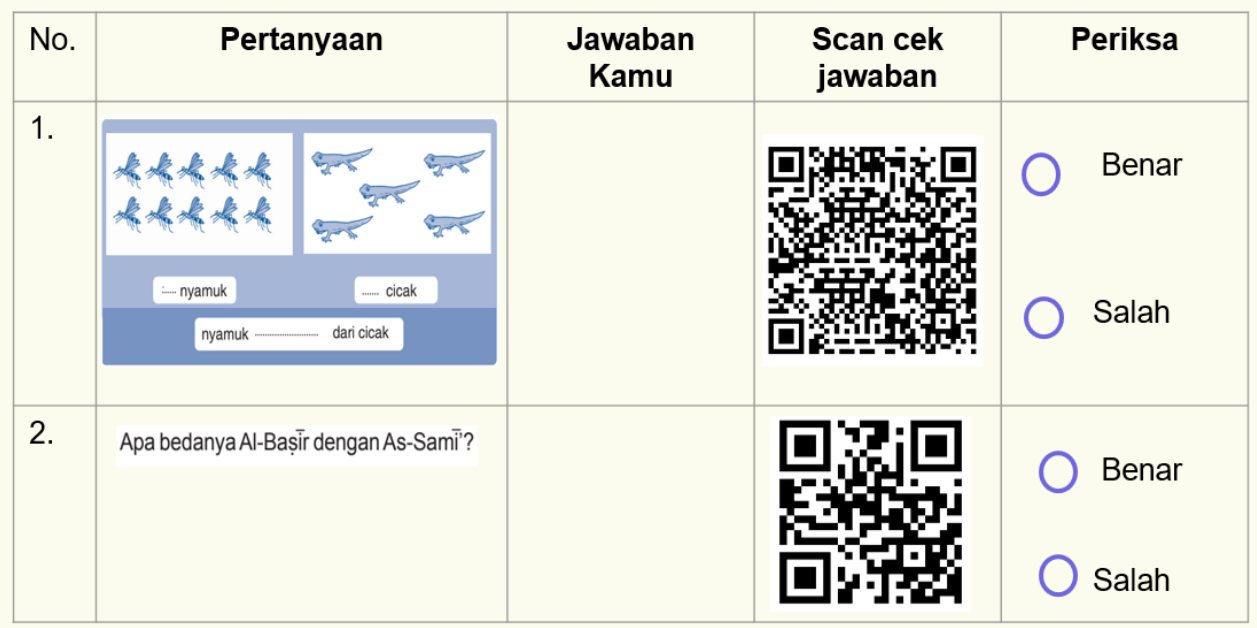

Gambar 5. Contoh Pembuatan bahan ajar dengan $Q R$ Code

Gambar 4 memperlihatkan Bahan ajar yang di $Q R$ Code adalah pelajaran matematika untuk soal no. 1, dimana diberikan sebuah gambar dan siswa akan memberikan jawabannya di kolom yang telah disediakan (jawaban kamu). Untuk melihat apakah jawaban tersebut benar, maka siswa akan scan $Q R$ Code yang ada dan apabila jawaban yang ditulis sama dengan jawaban pada $Q R$ Code maka siswa dapat membuat ceklis pada periksa, jika jawaban sama dengan $Q R$ Code-nya maka ceklis 
jawaban benar dan jika tidak sama maka ceklis tanda salah. Generate qrcode untuk jawaban no. 1 dapat dilihat pada gambar 5 .

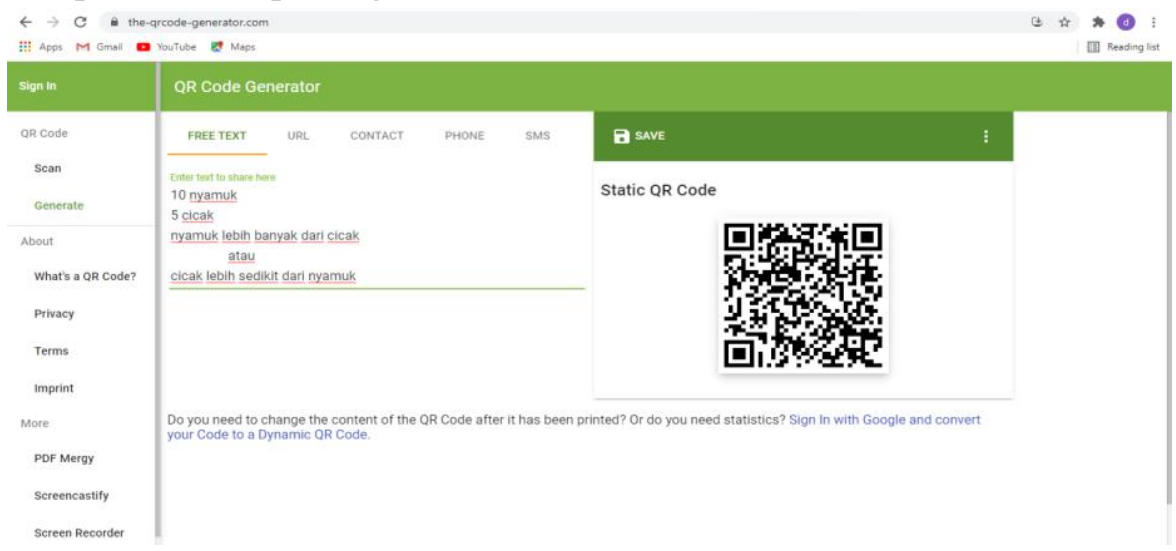

Gambar 6. contoh Generate Teks

Kegiatan hari ketiga dan keempat, dimana peserta mendemontrasikan secara langsung pembuatan bahan ajar dengan $Q R$ Code. Dalam hal ini, peserta dibagi menjadi 10 kelompok yang terdiri dari 3 peserta. Contoh hasil para peserta dapat dilihat pada gambar 6 dan 7 .

\begin{tabular}{|l|l|l|}
\hline & \multicolumn{2}{|c|}{ Tulis jawabannya disini : } \\
\hline & & \\
\hline
\end{tabular}

\section{Gambar 7. contoh pembelajaran interaktif kelompok 1}

Peserta pertama membuat pertanyaan tentang pancasila butir dan lambing Pancasila. Jawaban pertanyaan tersebut sudah di buar $Q R$ Code nya

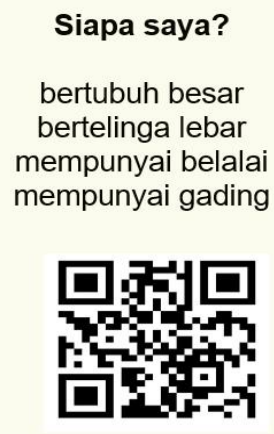

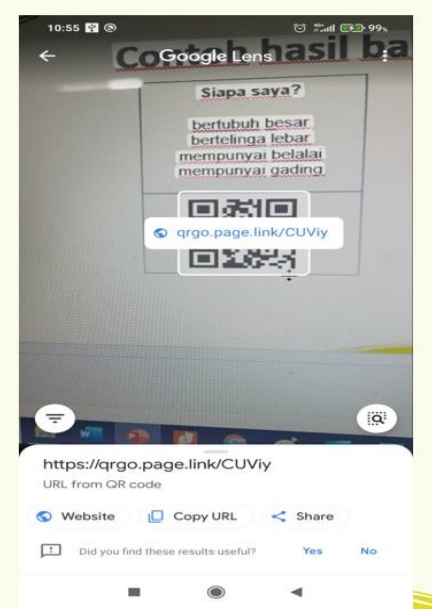

Gambar 8. contoh pelajaram interkatif kelompok 2 
Kelompok 2, membuat Qrcode berupa link youtube, dimana nantinya siswa akan mempelajri tentang link ada pada $Q R$ Code tersebut. Pada gambar 7 dimana untuk memulai pelajaran siswa akan diberikan pertanyaan tenatang siapa yang dimaksud, kemudian akan menscan $Q R$ Code untuk melihat pelajaran apa yang akan dipelajari hari itu secara lebih dalam lagi.

Pada hari keempat, peserta juga diberikan google form untuk diisi. Materi yang harus diisi sama dengan hari pertama, maksud dari pemberian pertanyaan ini adalah menilai kembali tingkat pemahaman peserta setelah mendapatkan materi.

Tahap terakhir dari kegiatan ini adalah tahap evaluasi, dimana tim membuat evaluasi kegiatan yang telah berlangsung. Pada hari pertama hasil pengisian goolgle form tentang pengenalan dan pemahaman tentang pembelajaran interaktif dengan $Q R$ Code bahwa 95\% peserta sudah mengenal $Q R$ Code, dari 95\% tersebut diketahui bahwa $3 \%$ sudah pernah menggunakan QRcode, namun hanya $1 \%$ saja yang menggunakan $Q R$ Code sebagai alat untuk pembelajaran yang interaktif.

Pada tahapan pelaksanaan terdapat permasalahan-permasalahan dalam melaksanakan kegiatan PKM ini, diantaranya internet yang tidak stabil yang mengakibatkan gangguan dalam menyampaikan materi sehingga tim harus mengulang materi yang mengakibatkan waktu yang digunakan untuk memaparkan materi lebih banyak. Dan juga peserta yang harus keluar ditengah-tengah kegiatan karena sinyal yang tidak stabil ini. Permasalahan ini, diselesaikan dengan membrikan rekaman kegiatan, karena tim melakukan perekaman kegitan menggunkan aplikasi recording yang ada.

Dari hasil demontrasi 7 kelompok, dapat dianalisis bahwa sekitar 93\% peserta sudah bisa menggunakan $Q R$ Code sebagai alat untuk pembelajaran yang interaktif dimana dibuktinya para peserta sudah dapat membuat dan mendemontrasikan secara baik dan benar. Sementara itu, hasil dari pengisian google form di hari keempat didapat 96\% peserta sudah bisa membuat pelajaran interaktif dengan $Q R$ Code .

\section{KESIMPULAN}

Setelah melaksanaakan pra pelaksanaan secara observasi maka ditemuakan permasalahan dalam metode yang digunakan yaitu guru hanya memberikan materi tanpa memberikan penjelasan tentang materi tersebut, penjelasan materi akan dipahami oleh orang tua dan yang kemudian mengajarkannya kepada siswa. Hal ini memiliki kelemahan dimana banyak orang tua yang tidak memahami materi tersebut, atau orang tua yang bekerja dirumah sehingga orang tua tidak memiliki waktu yang sama dengan waktu belajar anak yang mengakibatkan siswa tidak belajar sesuai dengan waktu yang di tentukan karena menunggu orangtua selesai bekerja.

Maka dari itu dibuatlah kegiatan pengabdian kepada masyarakat yang memperkenalkan dan pemberian Pelatihan Pemanfatan $Q R$ Code Technology dalam Pengembangkan Media Pembelajaran sehingga pembelajaran lebih menarik dan interaktif.

Dari hasil PKM tersebut, dapat dianalisis bahwa sekitar 93\% peserta sudah bisa menggunakan $Q R$ Code sebagai alat untuk pembelajaran yang interaktif dimana dibuktinya para peserta sudah dapat membuat dan mendemontrasikan secara baik dan benar. Sementara itu, hasil dari pengisian google form di hari keempat didapat $96 \%$ peserta sudah bisa membuat pelajaran interaktif dengan $Q R$ Code 


\section{DAFTAR PUSTAKA}

A. S. Narayanan, 2012. QR code and security solution. International Journal of Computer Science and Telecommunications, 3((7)), pp.69-71.

Burritt, R. \& Christ, K., 2016. Industry 4.0 and environmental accounting: a new revolution? Asian Journal of Sustainability and Social Responsibility, 1(1), pp.2338.

Davis, R., 2015. Industry 4.0: Digitalisation for productivity and growth, briefing for the European parliament (PE568.337). European Parliamentary Research Service.

Desyanti, D., Suhaidi, M. and Fitra, F. (2019) "Meningkatkan kemampuan menghafal juz amma melalui media pembelajaran audio visual", Unri Conference Series: Community Engagement, 1, pp. 297-303. doi: 10.31258/unricsce.1.297-303.

Hasibuan, M., 2019. Jurnal Pendidikan Bahasa dan Sastra Indonesia. Jurnal Pendidikan Bahasa dan Sastra Indonesia, 1(1), pp.44-59.

Prasetyo, B. \& Trisyanti, U., 2018. Revolusi Industri 4.0 Dan Tantangan Perubahan Sosial. IPTEK Journal of Proceedings Series, 0(5), pp.22-27.

Saenab, S., Syamsiah \& Saleh, A.R., 2017. Respon Mahasiswa Terhadap Penggunaan Quick Respon Code (QR Code) Pada Matakuliah Botani Tumbuhan Tinggi. Jurnal Bionature, 17(1), pp.58-62.

Sari, F. et al., 2021. Pelatihan Pembuatan Media Pembelajaran Sempoa Berbasis Teknologi Informasi. ABDINE: Jurnal Pengabdian Masyarakat, 1(1), pp.14-19.

Supriyanto, D., 2018. Pengaruh Penggunaan Media Pembelajaran Berbasis E-Learning. MODELING: Jurnal Program Studi PGMI, 5(1), pp.112-129. 